\title{
Pengaruh Keberadaan Universitas Haluoleo Terhadap Perubahan Tata Guna Lahan Di Kawasan Andonuohu Kota Kendari
}

\author{
Afriani Amiruddin1 \\ PT. Bank Panin, Tbk \\ Kota Kendari, Sulawesi Tenggara, Indonesia
}

\begin{abstract}
Abstrak: Universitas merupakan sarana yang menyediakan jasa pendidikan bagi masyarakat. Keberadaan universitas secara tidak langsung dapat mempengaruhi perkembangan suatu kawasan yang ditandai dengan banyaknya perubahan tata guna lahan. Adanya perubahan tata guna lahan juga dapat disebabkan oleh adanya pemusatan aktivitas masyarakat pada suatu kawasan. Universitas Haluoleo adalah satu-satunya universitas negeri yang berada di kota Kendari tepatnya di kawasan Andonuohu. Dalam RTRW Kota Kendari tahun 2010, kawasan Andonuohu merupakan kawasan yang dijadikan sebagai salah satu pusat pendidikan yaitu dengan adanya Universitas Haluoleo tersebut. Padatnya penduduk di daerah ini disebabkan karena keberadaan universitas ini dapat menarik penduduk luar kota Kendari yang ingin melanjutkan pendidikan di universitas tersebut. Penelitian ini bertujuan untuk mengetahui pengaruh keberadaan universitas terhadap perubahan tata guna lahan di sekitarnya. Dalam penelitian ini akan dilakukan beberapa analisis dimana untuk melakukan analisis menggunakan beberapa variabel yaitu jenis penggunaan lahan, sebaran penggunaan lahan dan besaran lahan yang digunakan. Adapun analisis yang digunakan dalam penelitian ini yaitu analisis sistem kegiatan yang muncul, analisis keterkaitan antar sistem kegiatan dan analisis perubahan lahan perubahan lahan yang terjadi akibat munculnya sistem kegiatan. Teknik analisis yang digunakan yaitu deskriptif kualitatif. Keberadaan universitas tersebut menyebabkan banyaknya sistem kegiatan yang mendukung keberadaan universitas tersebut seperti kegiatan privat, ekonomi, sosial maupun rekreasi. Sistem kegiatan tersebut menyebabkan sebagian besar lahan disekitar universitas mengalami perubahan yang berimplikasi pada lahan terbangun. Perubahan tata guna lahan yang terjadi yaitu banyaknya ruang terbuka hijau, tanah terbuka dan tambak yang berubah menjadi lahan permukiman dan perdagangan dan jasa. Akan tetapi perubahan lahan yang terjadi mengakibatkan perubahan fisik kearah yang kurang baik seperti berdirinya beberapa perdagangan dan beberapa pemukiman yang tidak teratur sehingga terkesan semerawut. Sistem kegiatan yang muncul ini mempunyai tujuan utama yaitu untuk memenuhi kebutuhan mahasiswa sehinggan bisa disimpulkan bahwa munculnya berbagai macam kegiatan ini merupakan dampak dari keberadaan Universitas Haluoleo. Munculnya sistem kegiatan yang ada dapat mendatangkan keuntungan yang besar dan secara tidak langsung dapat meningkatkan perekonomian kawasan tersebut. Keberadaan universitas ini membawa dampak terhadap perubahan lahan, dimana perubahan lahan yang terlihat pesat seperti berkembangnya lahan kegiatan perdagangan dan jasa, rekreasi dan penunjang seperti banyaknya lahan pertokoan di sepanjang jalan utama menuju kampus yaitu jalan MT. Haryono, AH.Nasution dan jalan H.M.E Mokodompit yang besarnya sekitar 13,7 Ha. Lahan permukiman juga mengalami peningkatan akibat keberadaan universitas tersebut karena semakin banyak penduduk terutama mahasiswa yang membutuhkan tempat tinggal. Adapun besar lahan permukiman
\end{abstract}

\footnotetext{
${ }^{1}$ Korespondensi Penulis: PT. Bank Panin, Tbk, Kota Kendari, Sulawesi Tenggara Email: afrianiamiruddin@ rocketmail.com
} 


\title{
74 Pengaruh Keberadaan Universitas Haluoleo Terhadap Perubahan Tata Guna Lahan...
}

yaitu 135,3 Ha. Jika dibandingkan antara tahun 2006 dengan tahun 2010 luas lahan perdagangan dan jasa pada tahun 2006 yaitu sebesar 5,9 Ha menjadi 13,7 Ha sedangkan untuk lahan permukiman dari 104,3 Ha pada tahun 2006 menjadi 135,3 Ha. Setelah dilakukan analisis dapat disimpulkan bahwa besar lahan dari masing-masing sistem kegiatan dapat dikatakan bahwa lahan permukiman sekitar $15,34 \%$, lahan perdagangan dan jasa sekitar $1,10 \%$, lahan rekreasi sekitar $0,062 \%$, dan lahan penunjang $0,39 \%$ dari luas lahan keseluruhan wilayah studi. Sebaran masing-masing sistem kegiatan tersebut menempati 2 kelurahan yaitu Kelurahan Lalolara dan Kelurahan Kambu dimana perkembangan kegiatan mencapai radius kurang lebih $2 \mathrm{~km}$ dari Universitas Haluoleo. Adapun yang dapat direkomendasikan melalui penelitian ini yaitu ditujukan untuk masyarakat maupun pemerintah. Rekomendasi untuk masyarakat itu sendiri adalah perlu adanya kesadaran bagi masyarakat terutama bagi para pelaku usaha untuk membangun usaha dengan kondisi yang layak agar terlihat teratur dan tidak semerawut dan adanya antisipatif bagi masyarakat khususnya bagi para pelaku usaha untuk menghadapi segala sesuatu seperti pencurian dan lain-lain. sedangkan untuk pemerintah adalah adanya peraturan dari pemerintah tentang izin mendirikan bangunan sehingga perdagangan dan jasa terlihat lebih teratur dan tidak semerawut dan adanya penataan aktivitas ekonomi khususnya disepanjang jalan H.M.E Mokodompit. Beberapa rekomendasi ini bertujuan untuk mengatasi pengaruh atau dampak yang ditimbulkan akibat perubahan lahan karena perkembangan aktivitas ekonomi yang disebabkan oleh keberadaan Universitas Haluoleo.

Kata Kunci: perubahan lahan, perubahan pola ruang, sistem kegiatan, universitas haluoleo

\begin{abstract}
University provides educational services for people in a country. The existence of the university may indirectly affect the development of a region marked by numerous changes in land use. A change in land use can also be caused by a concentration of activity in a region. Haluoleo University is a public university located at Andonuohu Kendari (South East Sulawesi). In a region of Kendari, Andonuohu serves as a center of education. Dense population in this area due to the existence of this university can attract people outside of Kendari who want to continue their education at the university. This study purposed to determine the effect of the presence of the university to changes in surrounding land use. This study will be conducted several analyzes in which to perform analyzes using multiple variables are the type of land use, land use and size distribution of land use. The analysis used in this study is the analysis of the emerging system of activities, analysis of the relationship between activity system and analyzes land use change land use changes that occur due to the emergence of system activity. Analysis technique used is descriptive qualitative. The existence of the university system resulted in many activities that support the existence of private universities such as activities, economic, social and leisure travelers. System activity caused most of the land surrounding the university have that implicates changes in land up. Changes in land use occurs which is the number of green open space, open land and farms being turned into residential land and trade and services. However, changes in land which has resulted in physical changes toward a less well as the establishment of several trade and some irregular settlements. This system of activities that appear to have the main goal is to meet the needs of students so can be concluded that the emergence of a wide range of activities is a result of the presence of Haluoleo University. The advent of the existing system of activity can bring huge profits and can indirectly increase the region's economy. The existence of this university have an impact on land use change, where change of land that looks like a rapidly growing field of trade and service activities, recreation and support as many area shops along the main road to the campus that is the way MT. Haryono and road HME AH.Nasution Mokodompit with approximately about 13.7 hectares of area. Land settlement has also increased due to the presence of the university as more and more people, especially students who need housing. The settlement of the land is 135.3 hectares. If the comparison between 2006 to 2010 trade and service area in 2006 is equal to 5.9 ha to 13.7 ha, while for the settlement of 104.3 hectares of land in 2006 to 135.3 ha. After analysis, we can conclude that the great land of each system can be said that the activities of
\end{abstract}


approximately $15.34 \%$ of land settlements, trade and service area of about $1.10 \%$, recreational land approximately $0.062 \%$ and $0.39 \%$ of the land area. Distribution of each system activity occupies two villages namely Lalolara Village and Village Kambu where development activity reached a radius of approximately $2 \mathrm{~km}$ from the University of Haluoleo. As can be recommended through this research that is aimed at community and government. Recommendations for the community itself is the need for public awareness, especially for business people to build businesses with the proper conditions to make it look organized and the anticipation for the community, especially for business people to deal with things like theft and others. while the government is the existence of government regulations on building permits so that trade and services appear more regularly and the structuring of economic activity, especially along the road Mokodompit HME. Some of these recommendations purposed for the influence or impact caused by land use changes due to developments in economic activity caused by the presence of Haluoleo University.

Keywords: University of Haluoleo, system activities, land use changes, changes in spatial pattern

\section{Pendahuluan}

Kota mengalami perkembangan sebagai akibat dari pertambahan penduduk, perubahan sosial ekonomi dan budayanya serta interaksinya dengan kota-kota lain dan daerah di sekitarnya. Secara fisik perkembangan suatu kota dapat dicirikan dari penduduknya yang semakin bertambah dan semakin padatnya bangunan terutama permukiman serta perdagangan dan jasa.

Perkembangan wilayah perkotaan menempati posisi yang dominan dalam kajian spasial karena wilayah kota cenderung lebih dinamis dan memiliki kompleksitas yang tinggi dibanding daerah pedesaan. Pertambahan penduduk perkotaan mendorong terjadinya peningkatan kegiatan kehidupan sosial dan ekonomi di kota, yang selanjutnya menyebabkan peningkatan kebutuhan terhadap lahan. Kebutuhan lahan di wilayah perkotaan berhubungan dengan pemenuhan kebutuhan bagi fasilitas dan utilitas kota, seperti: perumahan, perdagangan, jaringan air minum, jaringan sanitasi dan ruang terbuka hijau. Pada wilayah perkotaan, lahan dengan berbagai penggunaannya menempati urutan pertama dalam tingkat kompleksitas dan permasalahannya. Permasalahan penggunaan lahan merupakan permasalahan yang paling sering dijumpai pada wilayah perkotaan, misalnya: ketidaksesuaian penggunaan lahan eksisting dengan arahan fungsi ruang yang telah ditetapkan dalam Rencana Tata Ruang Kota, ketidakserasian dan ketidakseimbangan fungsi lingkungan dengan kawasan terbangun.

Adanya perubahan tata guna lahan juga dapat disebabkan oleh adanya pemusatan aktivitas masyarakat pada suatu kawasan. Hampir setiap aktivitas manusia melibatkan penggunaan lahan dan karena jumlah serta aktivitas manusia bertambah dengan cepat, maka lahan menjadi sumber yang langka. Fenomena alih fungsi lahan senantiasa terjadi dalam pemenuhan aktivitas sosial ekonomi yang menyertai pertumbuhan penduduk kota. Persediaan lahan yang bersifat tetap sedangkan permintaannya yang terus bertambah menjadikan penggunaan lahan suatu kota berubah ke arah aktivitas yang lebih menguntungkan dilihat dari potensi sekitarnya yang ada. Perubahan pemanfaatan ruang banyak terjadi pada kawasan dimana ada pusat aktivitas masyarakat dan pada umumnya perubahan pemanfaatm tersebut untuk mendukung aktivitas utama yang ada. Perubahan pemanfaatan lahan tersebut seperti yang terjadi di kota Kendari khususnya di sekitar Universitas Haluoleo tepatnya di kawasan Andonuohu.

Kota Kendari merupakan salah satu kota di Indonesia yang sedang dalam perkembangan. Pengembangan kota Kendari ini diarahkan pada bagian selatan wilayah 


\section{Pengaruh Keberadaan Universitas Haluoleo Terhadap Perubahan Tata Guna Lahan...}

Kota Kendari, yang meliputi Kecamatan Poasia dan Kecamatan Kambu dimana kedua kecamatan ini merupakan kecamatan yang berada pada kawasan Andonuohu. Pengembangan pada wilayah tersebut dilakukan karena ketersediaan lahan yang masih relatif luas dan aksesibitas yang cukup mudah. Pengembangan kota yang dilakukan selain berdampak bagi pertumbuhan kota juga menimbulkan beberapa permasalahan, khususnya perubahan dan ketidaksesuaian peruntukan fungsi lahan. Seperti yang terlihat pada pembagian BWK Kota Kendari tahun 2010, khusunya untuk BWK V merupakan kawasan Andonuohu yang berfungsi sebagai pusat pendidikan, pusat kesehatan, pusat perdagangan regional dan pusat pemerintahan Provinsi Sulawesi Tenggara. Kawasan Andonuohu sebagian kawasan yang terdiri dari rawa dan tambak dimana kawasan ini sangat sepi oleh penduduk. Salah satunya dalam kawasan Andonuohu ini merupakan pusat pendidikan dimana dengan adanya pemusatan pendidikan yaitu keberadaan Universitas Haluoleo ini maka kawasan ini menjadi ramai dan padat penduduk.

Keberadaan universitas ini membawa dampak terhadap perkembangan kawasan yaitu dengan banyaknya perubahan tata guna lahan yang terjadi khususnya wilayah Andonuohu. Perubahan tata guna lahan yang terjadi seperti perubahan lahan kosong atau tambak dna rawa menjadi lahan permukiman serta perdagangan dan jasa atau berubahnya lahan permukiman menjadi lahan perdagangan dan sebaliknya. Sebelum adanya Universitas Haluoleo kawasan Andonuohu merupakan kawasan yang sepi dan terkesan menakutkan. Lahan di kawasan Andonuohu didominasi oleh rawa serta tambak dan kawasan permukiman masih sangat sedikit. Namun dengan adanya Universitas Haluoleo ini perubahan tata guna lahan sangat berkembang mulai yaitu berubahnya lahan rawa dan tambak menjadi lahan terbangun.

\section{Tujuan Penelitian}

Penelitian ini bertujuan untuk mengetahui pengaruh keberadaan Universitas Haluoleo terhadap perubahan tata guna lahan di kawasan Andonuohu Kota Kendari yang selanjutnya dapat dijadikan sebagai dasar dalam menentukan kebijakan Tata Ruang khususnya terkait perkembangan wilayah khususnya kawasan Anduonohu.

\section{Kajian Literatur}

Perroux mengembangkan teorinya pada tahun 1955 atas dasar pengamatannya terhadap proses pembangunan. Pembangunan tidak terjadi secara serentak akan tetapi muncul di tempat-tempat tertentu dengan intensitas yang berbeda. Tempat-tempat itulah yang dinamakannya titik-titik pertumbuhan atau kutub-kutub pertumbuhan (growth poles). (Perroux, 1955 dalam Daldjoeni, 1978:142)

Pusat pertumbuhan (growth pole) dapat diartikan dengan dua cara, yaitu secara fungsional dan secara geografis. Secara fungsional, pusat pertumbuhan adalah suatu lokasi konsentrasi kelompok usaha atau cabang industri yang karena sifat hubungannya memiliki unsur -unsur kedinamisan sehingga mampu menstimulasi kehidupan ekonomi baik ke dalam maupun ke luar (daerah belakangnya). Secara geografis, pusat pertumbuhan adalah suatu lokasi yang banyak memiliki fasilitas dan kemudahan sehingga menjadi pusat daya tarik (pole of attraction), yang menyebabkan berbagai macam usaha tertarik untuk berlokasi di situ dan masyarakat senang datang memanfaatkan fasilitas yang ada di kota tersebut. Pusat pertumbuhan harus memiliki empat ciri, yaitu adanya hubungan intern antara berbagai macam kegiatan yang memiliki nilai ekonomi, adanya multiplier effect (unsur pengganda), adanya konsentrasi geografis dan bersifat mendorong pertumbuhan daerah belakanganya (Tarigan,2003:115). 
- Adanya Hubungan Internal dari Berbagai Macam Kegiatan

- Ada Efek Pengganda (Multiplier Effect)

- Ada Konsentrasi Geografis

- Bersifat Mendorong Daerah Belakangnnya

Teori model multiple nuclei mensugestikan bahwa banyaknya wilayah kota yang berkembangannya tidak mengelilingi CBD, akan tetapi oleh integrasi yang gradual dari beberapa nucleus (inti) yang terpisah-pisah kedalam struktur kota. (Daldjoeni,1978:142143). Teori ini menyebutkan bahwa pertumbuhan kota bermula dari suatu pusat menjadi ruwet bentuknya. Ini disebabkan oleh munculnya pusat-pusat tambahan yang masingmasing akan berfungsi menjadi kutub pertumbuhan. Disekelilingi nukleus- nukleus baru itu akan mengelompok tata guna tanah yang bersambungan secara fungsional. Tempattempat yang bertipe nukleus itu misalnya pelabuhan udara, kompleks industry, kampus universitas, pelabuhan laut atau stasiun besar. (Daldjoeni,1998: 193). Kemampuan suatu nukleus itu menyebarkan kutub pertumbuhan tersebut bergantung pada multiplier effect yang secara tidak langsung berhubungan dengan faktor-faktor input-output dari nukleus itu sendiri. Keberadaan universitas ini menjadi sebuah kutub pertumbuhan yang akan mempengaruhi wilayah sekitarnya seperti munculnya berbagai macam aktivitas ekonomi yang bertujuan menyediakan berbagai macam kebutuhan pendidikan. Selain itu, penggunaan lahan disekitar universitas juga bisa berupa berkembangnya lahan permukiman serta aktivitas lainnya.

Perubahan guna lahan terdiri dari beberapa karakteristik yang ada seperti adanya sebaran pemanfaatan lahan (sebaran ruang), jenis penggunaan lahan serta luasan dari masing-masing penggunaan lahan tersebut. Dimana besaran pemanfaatn lahan yaitu suatu besaran atau ukuran besarnya lahan yang digunakan suatu kegiatan dan Sebaran perubahan lahan merupakan letak sistem kegiatan itu berada. Sedangkan faktor-faktor yang mempengaruhi pengembangan guna lahan yaitu: topografi, penduduk, nilai lahan, aksesibilitas, sarana prasarana, dan daya dukung lingkungan. Suatu tingkah laku serta tindakan manusia merupakan faktor penentu dalam suatu penggunaan lahan. Hal ini disebabkan oleh tingkah laku manusia meliputi kebutuhan dan keinginan manusia dalam kehidupan sosial maupun kehidupan ekonomi. Dengan adanya kebutuhan manusia tersebut maka secara tidak langsung dapat mempengaruhi penggunaan lahan pada suatu kawasan yang berimplikasi pada lahan terbangun. Menurut Anthony J. Catanese (1986:317) bahwa suatu penggunaan lahan dapat dipengaruhi oleh manusia, aktivitas dan lokasi.

Terdapat tiga sistem yang mempengaruhi guna lahan yaitu (Chappin,1979:28-31) Sistem Aktivitas Kota, Sistem Pengembangan Lahan, dan Sistem Lingkungan. Berikut tabel sistem yang mempengaruhi penggunaan lahan, sebagai berikut:

Tabel 1. Sistem Kegiatan yang Mempengaruhi Penggunaan Lahan

\begin{tabular}{l|ll}
\hline \multicolumn{1}{c|}{ Pemeran } & \multicolumn{1}{c}{ Kegiatan } \\
\hline Individu dan keluarga & - & Kegiatan Keluarga \\
& - & Kegiatan bersosial/bermasyarakat \\
& - & Kegiatan rekreasi \\
& - & Kegiatan berbelanja \\
& - & Kegiatan bekerja \\
\hline Perusahaan & - & Kegiatan memproduksi barang \\
& - & Kegiatan memberikan jasa \\
\hline Institusi & - & Pengembangan SDM \\
& - & Kegiatan pelayanan publik \\
\hline Sumber: Chapin, 1979 &
\end{tabular}




\section{Metodologi Penelitian}

\section{Pendekatan Penelitian}

Studi kasus penelitian ini yaitu pengaruh keberadaan Universitas Haluoleo terhadap perubahan tata guna lahan di kawasan Andonuohu. Adapun pendekatan penelitian yang digunakan yaitu gabungan pendekatan kualitatif dan kuantitatif (mixed method). Metode gabungan (mixed method) ini berkaitan dengan penggunaan metode lebih dari satu dalam satu kegiatan penelitian yang menggunakan pendekatan kuantitatif dan kualitatif. Dalam penelitian ini data kuantitatif dan kualitatif digunakan sebagai bukti empiris dalam menjawab rumusan masalah penelitian agar mendapatkan hasil temuan yang lengkap.(Sarwono,2011:1-2).

\section{Objek Penelitian dan Populasi}

Objek penelitian dan populasi dari penelitian ini yaitu pelaku usaha yang berada di sekitar Universitas Haluoleo. Dimana objek penelitian tersebut akan memunculkan berbagai macam sistem kegiatan yang akan mempengaruhi perubahan tata guna lahan di kawasan Andonuohu khususnya sekitar Universitas Haluoleo. Adapun beberapa wilayah yang terkena dampak dari keberadaan universitas tersebut yaitu kecamatan Kambu khususnya di Kelurahan Kambu dan Kelurahan Lalolara.

\section{Jenis Data}

Jenis data yang digunakan pada penelitian ini dikelompokkan menjadi dua macam, yaitu Data Primer dan Data Sekunder.

- Data Primer yaitu data yang diperoleh langsung dari objek penelitian melalui kegiatan pengukuran, pengamatan langsung dan pengecekan lapangan (groundcheck) pada saat observasi lapangan.

- Data Sekunder diperoleh dari telaahan terhadap beberapa dokumen perencanaan, seperti RTRW Kota Kendari tahun 2000-2010, peta-peta penggunaan lahan yang berkaitan dengan objek yang diteliti dan studi/penelitian-penelitian yang telah dilakukan sebelumnya

\section{Metode Pengumpulan Data}

Metode pengumpulan data yang dilakukan dalam penelitian ini yaitu :

- Observasi, metode ini digunakan untuk mengetahui sistem kegiatan yang muncul akibat keberadaan kampus yang berimplikasi pada lahan terbangun serta melihat dampak perubahan yang terjadi akibat sistem kegiatan tersebut. Observasi dilakukan pada 2 kelurahan yaitu Kelurahan Kambu dan Kelurahan Lalolara.

- Wawancara, wawancara ini dilakukan kepada pelaku usaha yang berada disekitar universitas sehingga dapat diketahui hal apakah yang menjadi pemicu munculnya usaha yang didirikan disekitar kampus tersebut.

- Studi literatur, metode ini dilakukan dengan mengumpulkan data spasial dan data atribut dari instansi terkait untuk mendapatkan data yang memiliki relevansi dengan penelitian ini. Studi literatur ini juga dimaksudkan untuk pendalaman konsep/teoriteori tentang penggunaan lahan serta dari berbagai sumber, baik dari buku, dokumen (RTRW Kota Kendari tahun 2000-2010), jurnal, artikel, karya ilmiah dan lain-lain.

\section{Teknik Sampling}

Untuk mengetahui populasi jenis usaha di sekitar universitas dengan menggunakan purposif sampling mengingat jumlahnya di sekitar universitas sangat banyak dan tersebar 
dimana-mana. Purposif sampling dilakukan untuk mengambil sampel secara acak kepada orang-orang yang telah terpilih oleh peneliti yang telah memiliki ciri-ciri spesifik yang dimiliki oleh sampel. Selain itu, penentuan sampel yang akan diwawancarai ini sesuai dengan kategori yang ditentukan oleh peneliti dimana dengan adanya pengkategorian tersebut berfungsi untuk mendapatkan sampel yang benar-benar bisa memberikan informasi mengenai peristiwa, situasi yang diobservasikan dan informasi yang diperlukan oleh peneliti.

Dalam penelitian tersebut, dilakukan metode ini untuk mengambil sampel dari beberapa jenis usaha yang berada di sekitar universitas tersebut. Karena para pelaku usaha disekitar kampus ini sangat banyak maka digunakan metode tersebut agar bisa mewakili dari beberapa yang ada. Sehingga dapat diketahui sistem kegiatan apa saja yang dilakukan oleh pelaku usaha tersebut. Adapun kriteria yang ditentukan dalam menentukan sampel yaitu:

- Usaha yang berdiri sebagian besar untuk memenuhi kebutuhan mahasiswa diantara lain:

a. Usaha yang memenuhi kebutuhan untuk bermukin seperti kos-kosan dan kontrakan

b. Usaha perdagangan dan jasa seperti counter pulsa, rental komputer, foto copy, rumah makan, apotik, warung kecil, penjual meubel, aksesoris kendaraan, dan minimarket

c. Usaha yang memenuhi kebutuhan rekreasi seperti tempat persewaan komik, rental VCD, lapangan futsal indoor, dan game center

d. Usaha yang memenuhi kebutuhan penunjang lainnya seperti salon, bengkel, butik, laundry, dan lain-lain

- Usaha yang sifatnya berkumpul pada suatu tempat atau lokasi. Penelitian ini dilakukan wawancara sebanyak 28 orang pelaku usaha yang berada di Kelurahan Lalolara dan Kelurahan Kambu. Adapun pelaku usaha yang diwawancarai yaitu:

a. Usaha kos-kosan sebanyak 3 orang. Usaha kos-kosan yang diwawancarai yaitu kos-kosan yang memiliki kamar mandi dalam dan kos-kosan yang menggunakan kamar mandi luar

b. Perdagangan dan jasa sebanyak 17 orang. Perdagangan dan jasa yang diwawancarai yaitu perdagangan dan jasa yang menempati kompleks pertokoan, bangunan papan serta PKL

c. Aktivitas rekreasi sebanyak 3 orang

d. Aktivitas penunjang sebanyak 5 orang.

\section{Metode Analisis}

Metode analisis yang digunakan dalam penelitian ini yaitu metode analisis deskriptif kualitatif. penelitian deskriptif kualitatif. Penelitian deksriptif ini bertujuan untuk memaparkan suatu deskripsi, gambaran secara sistematis, faktual serta akurat menganei fakta-fakta di wilayah studi. Penelitian deskriptif mempelajari mengenai permasalahan penduduk, tata cara yang berlaku dalam lingkungan penduduk, kondisi-kondisi tertentu termasuk hubungan dalam antar suatu kegiatan serta pandangan-pandangan dan prosesproses ataupun pengaruh- pengaruh yang sedang berlangsung dalam suatu fenomena. (Whitney, dalam Nasir, 1988:63). Data-data yang diperoleh kemudian disajikan dalam bentuk tabel, grafik dan kemudian dideskripsikan sehingga menghasilkan informasi kualitatif. Analisis deskriptif kualitatif yaitu teknik analisis dengan cara mentransformasikan data hasil wawancara atau non numerik kedalam suatu data yang bisa di mengerti, sehingga menghasilkan suatu informasi yang dibutuhkan untuk menjawab penelitian yang dilakukan. Analisis ini digunakan dengan cara menjelaskan secara deskriptif mengenai perkembangan aktivitas ekonomi di sekitar universitas seperti jenis usaha dan sebaran 


\section{Pengaruh Keberadaan Universitas Haluoleo Terhadap Perubahan Tata Guna Lahan...}

masing aktivitas ekonomi. Sedangkan untuk mengetahui besaran lahan yang digunakan untuk masing-masing usaha yaitu dengan menggunakan metode analisis kuantitatif. Dalam menggunakan metode tersebut, peneliti menghitung jumlah besar lahan yang dipakai untuk masing-masing usaha sehingga dapat diketahui seberapa besar lahan (Ha) yang digunakan di wilayah studi untuk masing-masing sistem kegiatan.

\section{Analisis Sistem Kegiatan}

Berdasarkan dari hasil observasi yang dilakukan, ada beberapa hal yang menjadi akibat dari keberadaan universitas di suatu wilayah. Seperti halnya yang terjadi di sekitar Universitas Haluoleo, terdapat banyaknya perubahan lahan yang terjadi, akibat bertambahnya pula berbagai macam aktivitas atau kegiatan baik untuk memenuhi kebutuhan mahasiswa maupun kebutuhan penduduk sekitar. Adapun sistem kegiatan atau aktivitas yang dimaksud yaitu sebagai berikut:

Tabel 2. Klasifikasi Sistem Kegiatan yang Muncul

\begin{tabular}{|c|c|c|c|}
\hline Pelaku & Kegiatan & Guna Lahan & Konsumen Utama \\
\hline \multirow{5}{*}{$\begin{array}{l}\text { Per orangan dan } \\
\text { Keluarga }\end{array}$} & $\begin{array}{l}\text { - Kegiatan Keluarga } \\
\text { a. Perumahan } \\
\text { b. Kosan } \\
\text { c. Kontrakan }\end{array}$ & Permukiman & \multirow{5}{*}{$\begin{array}{c}\text { Konsumen utama yaitu } \\
\text { mahasiswa dan } \\
\text { sebagian kecil yaitu } \\
\text { penduduk sekitar }\end{array}$} \\
\hline & $\begin{array}{l}\text { - Kegiatan Sosial/ } \\
\text { Bermasyarakat } \\
\text { a. Tempat ibadah (masjid } \\
\text { dan gereja) }\end{array}$ & Peribadatan & \\
\hline & $\begin{array}{l}\text { - Kegiatan Rekreasi } \\
\text { a. Tempat persewaan } \\
\text { komik } \\
\text { b. Rental VCD } \\
\text { c. Lapangan futsal indoor } \\
\text { d. Game Center }\end{array}$ & Perdagangan dan jasa & \\
\hline & e. Ruang Terbuka Hijau & RTH & \\
\hline & $\begin{array}{l}\text { - Kegiatan Penunjang } \\
\text { a. Salon } \\
\text { b. Bengkel } \\
\text { c. Butik } \\
\text { d. Laundry } \\
\text { e. dll } \\
\end{array}$ & Perdagangan dan jasa & \\
\hline Perusahan & $\begin{array}{l}\text { - Kegiatan memproduksi } \\
\text { barang: pembuatan dan } \\
\text { penjualan meubel } \\
\text { - Kegiatan memberikan jasa: } \\
\text { a. Counter pulsa } \\
\text { b. Fotocopy / penjualan } \\
\text { ATK } \\
\text { c. Rumah makan } \\
\text { d. Minimarket } \\
\text { e. Apotek } \\
\text { f. Warung kecil } \\
\text { g. Rental computer } \\
\text { h. Warung internet } \\
\text { i. Penjualan aksesoris } \\
\text { kendaraan }\end{array}$ & Perdagangan dan jasa & $\begin{array}{l}\text { Konsumen utama yaitu } \\
\text { mahasuswa dan } \\
\text { sebagian kecil yaitu } \\
\text { penduduk sekitar }\end{array}$ \\
\hline
\end{tabular}




\begin{tabular}{|c|c|c|c|}
\hline Pelaku & Kegiatan & Guna Lahan & Konsumen Utama \\
\hline Institusi & $\begin{array}{l}\text { Kegiatan pelayanan publik } \\
\text { a. Badan Pertanahan } \\
\text { Nasional Kota Kendari } \\
\text { b. Ban BNI Cabang } \\
\text { Andonuohu } \\
\text { c. Asuransi Syariah } \\
\text { d. Kantor Kelurahan } \\
\text { Kambu } \\
\text { e. Kantor Kelurahan } \\
\text { Lalolara }\end{array}$ & Perkantoran & $\begin{array}{c}\text { Konsumen utama yaitu } \\
\text { penduduk sekitar dan } \\
\text { sebagian kecil yaitu } \\
\text { mahasiswa }\end{array}$ \\
\hline
\end{tabular}

Munculnya berbagai macam kegiatan diwilayah studi, secara tidak langsung dapat dilihat bagian-bagian wilayah mana sajakah yang dominan kegiatan perdagangan dan jasa, permukiman, maupun kegiatan pendidikan. Untuk kegiatan perdagangan dan jasa sangat dominan di sepanjang jalan utama sedangkan kegiatan permukiman tersebar di dua kelurahan tersebut. Terlihat jumlah jenis usaha yang tersebar bahwa usaha yang paling banyak yaitu terletak di Kelurahan Lalolara, hal ini disebabkan karena kelurahan tersebut terletak disepanjang jalur utama menuju Universitas Haluoleo yaitu di Jalan MT. Haryono dan jalan H.E.A Mokodompit. Munculnya berbagai macam kegiatan tersebut ada beberapa yang memiliki dampak secara langsung maupun tidak secara langsung berhubungan dengan universitas. Berikut merupakan foto mapping penggunaan lahan di wilayah studi:

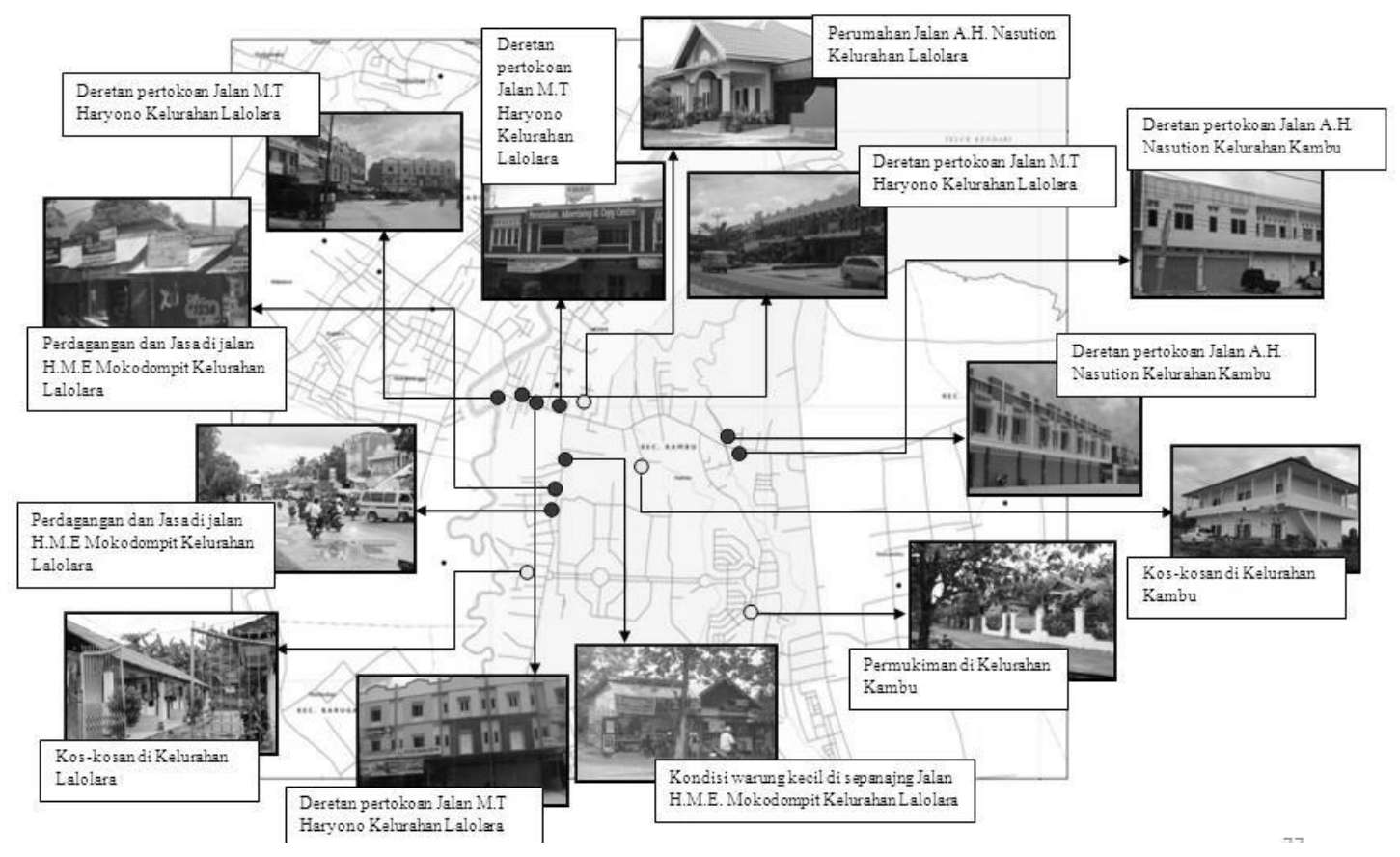

Gambar 1. Foto Mapping Penggunaan Lahan di Kelurahan Kambu dan Kelurahan Lalolara 


\section{2}

Pengaruh Keberadaan Universitas Haluoleo Terhadap Perubahan Tata Guna Lahan...

\section{Analisis Keterkaitan Sistem Kegiatan}

Keberadaan Universitas Haluoleo telah memberikan dampak terhadap perkembangan aktivitas ekonomi disekitar kampus. Adapun dampak yang muncul baik itu backward linkage maupun forward linkage. Kegiatan yang muncul merupakan kegiatan yang dipengaruhi oleh keberadaan universitas secara langsung (backward linkage) maupun kegiatan kedepannya pendukung kegiatan sebelumnya (forward linkage). Backward linkage dari keberadaan kampus yaitu banyaknya lahan tidak terbangun atau lahan kosong dan adanya pelaku aktivtitas pendidikan di Universitas Haluoleo yaitu mahasiswa, dosen serta pegawai tata usaha. Adanya backward linkage tersebut dapat memacu perkembangan aktivitas lainnya (forward linkage). Adapun forward linkage yang muncul yaitu berbagai macam aktivitas ekonomi terutama yang mendukung keberadaan universitas tersebut. Forward linkage yang dimaksud yaitu pemenuhan kebutuhan tempat tinggal seperti koskosan, kontrakan maupun perumahan untuk penduduk sekitar, rumah makan, rental komputer, warnet, minimarket, warung kecil, butik, bengkel, persewaan komik, warung kecil, game center, forocopy/penjualan ATK, apotik, salon dan lain- lain.

Beberapa forward linkage yang muncul maka dapat digolongkan kedalam beberapa sistem kegiatan yang ada seperti sistem kegiatan bermukim, perdagangan dan jasa, rekreasi dan penunjang. Dalam hal ini, kegiatan yang muncul diatas akan diuji keterkaitannya dengan universitas, dimana munculnya beberapa kegiatan diatas memiliki keterkaitan dengan keberadaan universitas seperti yang terlihat pada tabel dibawah ini:

Tabel 3. Keterkaitan antar Jenis Kegiatan dengan Universitas Haluoleo

\begin{tabular}{|c|c|c|c|c|c|}
\hline Jasa Pen- & & Univer & luoleo & & \\
\hline $\begin{array}{l}\text { Sistem } \\
\text { Kegiatan }\end{array}$ & Perkuliahan & Privat & Ekonomi & Sosial & Total \\
\hline Bermukim & $\checkmark$ & $\checkmark$ & $\checkmark$ & & 3 \\
\hline $\begin{array}{c}\text { Perdagangan } \\
\text { dan Jasa }\end{array}$ & $\checkmark$ & $\checkmark$ & $\checkmark$ & $\checkmark$ & 4 \\
\hline Rekreasi & & & $\checkmark$ & & 1 \\
\hline Penunjang & & $\checkmark$ & $\checkmark$ & & 2 \\
\hline
\end{tabular}

Setelah dilakukan analisis, dapat dilihat jenis kegiatan perdagangan dan jasa memiliki total 4 , kegiatan bermukim memiliki total 3 , kegiatan penunjang memiliki total 2 dan kegiatan rekreasi memiliki total sebanyak 1. Dalam menggunakan tabel diatas sudah dapat diketahui kegiatan manakah yang lebih banyak terkait dengan keberadaan Universitas Haluoleo. Sehingga dapat diambil diambil kesimpulan bahwa kegiatan perdagangan dan jasa memiliki nilai paling tinggi diantara kegiatan lainnya atau bisa dikatakan bahwa kegiatan yang paling banyak terkait dengan universitas.

\section{Analisis Perubahan Lahan yang Terjadi Karena Munculnya Sistem Kegiatan di Sekitar Universitas Haluoleo}

Pola penggunaan lahan dapat berubah sesuai dengan perkembangan kebutuhan dan kemajuan manusia. Perubahan pola pemanfaatan lahan akan menimbulkan suatu fenomena yaitu satu pemanfaatan lahan dikorbankan untuk pemanfaatan lainnya. Misalnya, pemanfaatan lahan yang awalnya berfungsi sebagai tambak, berubah menjadi lahan permukiman atau fasilitas lainnya. Keberadaan Universitas Haluoleo sangat 
membawa pengaruh yang besar terhadap perubahan tata guna lahan di sekitarnya. Lahan yang sebelumnya berupa tambak dan lahan kosong sekarang telah berubah menjadi lahan terbangun. Padatnya bangunan di sekitar kampus menyebabkan tidak teraturnya bangunan terutama perdagangan dan jasa yang berada di depan kampus sehingga terlihat semerawut. Perubahan lahan yang terjadi juga sangat terlihat dengan banyaknya pertokoan yang dibangun disepanjang jalan utama yaitu Jalan. MT. Haryono, Jalan H.M.E Mokodompit dan Jalan A.H Nasution. Berikut merupakan data penggunaan lahan di Kelurahan Lalolara dan Kelurahan Kambu:

Tabel 4. Data Penggunaan Lahan di Kelurahan Lalolara dan Kelurahan Kambu Tahun 2006 dan 2010

\begin{tabular}{l|c|l|c}
\hline $\begin{array}{c}\text { Penggunaan Lahan } \\
\text { Tahun 2006 }\end{array}$ & Besaran (Ha) & \multicolumn{1}{|c}{$\begin{array}{c}\text { Penggunaan Lahan } \\
\text { Tahun 2010 }\end{array}$} & Besaran (Ha) \\
\hline Tambak & 224,9 & Tambak & 207,3 \\
\hline Permukiman & 104,3 & Permukiman & 135,3 \\
\hline Hutan Mangrove & 40,6 & Hutan Mangrove & 35,6 \\
\hline Semak & 41,8 & Semak & 36,1 \\
\hline Ruang Terbuka Hijau & 284,7 & Ruang Terbuka Hijau & 269,5 \\
\hline Tanah Terbuka & 150,1 & Tanah Terbuka & 131,4 \\
\hline Pendidikan & 27,4 & Pendidikan & 27,2 \\
\hline Fasilitas Olahraga & 1,7 & Fasilitas Olahraga & 1,5 \\
\hline Perdagangan dan Jasa & 5,9 & Perdagangan dan Jasa & 13,7 \\
\hline Kesehatan & 0,2 & Kesehatan & 0,6 \\
\hline Peribadatan & 0,7 & Peribadatan & 0,8 \\
\hline Perkantoran & 0,7 & Perkantoran & 0,7 \\
\hline \multicolumn{1}{c}{ Jumlah } & $\mathbf{8 8 3}$ & Hutan & 13,2 \\
\hline \multicolumn{2}{r}{} & Padang Rumput & 10,1 \\
\cline { 2 - 4 } & Jumlah & $\mathbf{8 8 3}$
\end{tabular}

Sumber: BPN Kota Kendari dan Monografi Kelurahan, 2010

Berdasarkan tabel diatas dapat terlihat perubahan lahan yang terjadi dari tahun 2006 ketahun 2010, dapat disimpulkan bahwa terjadi perubahan mulai dari lahan terbangun pada tahun 2006 sebesar 140,9 Ha dan pada tahun 2010 menjadi 178,4 Ha. Sedangkan untuk lahan non terbangun pada tahun 2006 sebesar 742,1 Ha dan pada tahun 2010 berkurang menjadi 704,6 Ha. Lahan tidak terbangun seperti rawa, semak, tambak, tanah terbuka dan lain-lain mengalami perubahan lahan terbangun seiring dengan keberadaan Universitas Haluoleo yang menyebabkan perkembangan kawasan sekitar.

Sebagian besar perubahan lahan yang terjadi di wilayah studi lebih kepada banyaknya pembangunan pertokoan disepanjang jalan utama yaitu jalan MT. Haryono dan Jalan A.H Nasution, sehingga banyak investor yang membuka usaha untuk memenuhi kebutuhan mahasiswa maupun penduduk sekitar. Dibawah ini merupakan tabel bentuk perubahan lahan yang terjadi di wilayah studi:

\section{Tabel 5. Bentuk Perubahan Lahan}

\begin{tabular}{l|l|l|l|l|l|l}
\hline Perubahan & \multicolumn{2}{|c|}{ Perubahan Lahan } & \multicolumn{1}{|c|}{$\begin{array}{c}\text { Bentuk } \\
\text { Perubahan }\end{array}$} & $\begin{array}{c}\text { Besaran } \\
\text { Lahan } \\
\text { (Ha) }\end{array}$ & $\begin{array}{l}\text { Sebaran } \\
\text { Aktivitas } \\
\text { (kelurahan) }\end{array}$ & Keterangan \\
\cline { 2 - 5 } & $\begin{array}{l}\text { Lahan } \\
\text { Sebelumnya }\end{array}$ & $\begin{array}{l}\text { Lahan } \\
\text { Sekarang }\end{array}$ & & $\begin{array}{l}\text { Kelurahan } \\
\text { Kambu dan }\end{array}$ & $\begin{array}{l}\text { Data } \\
\text { didapatkan } \\
\text { berdasarkan } \\
\text { survey } \\
\text { sekunder }\end{array}$ \\
\hline
\end{tabular}


84 Pengaruh Keberadaan Universitas Haluoleo Terhadap Perubahan Tata Guna Lahan...

\begin{tabular}{|c|c|c|c|c|c|c|}
\hline \multirow[t]{2}{*}{ Perubahan } & \multicolumn{2}{|c|}{ Perubahan Lahan } & \multirow{2}{*}{$\begin{array}{c}\text { Bentuk } \\
\text { Perubahan }\end{array}$} & \multirow{2}{*}{$\begin{array}{c}\text { Besaran } \\
\text { Lahan } \\
\text { (Ha) }\end{array}$} & \multirow{2}{*}{$\begin{array}{c}\text { Sebaran } \\
\text { Aktivitas } \\
\text { (kelurahan) }\end{array}$} & \multirow[t]{2}{*}{ Keterangan } \\
\hline & $\begin{array}{l}\text { Lahan } \\
\text { Sebelumnya }\end{array}$ & $\begin{array}{l}\text { Lahan } \\
\text { Sekarang }\end{array}$ & & & & \\
\hline $\begin{array}{l}\text { Perdagang- } \\
\text { an dan jasa }\end{array}$ & $\begin{array}{l}\text { Ruang } \\
\text { terbuka } \\
\text { hijau, } \\
\text { tambak, } \\
\text { tanah } \\
\text { terbuka }\end{array}$ & Terbangun & $\begin{array}{l}\text { Rumah makan, } \\
\text { rental } \\
\text { komputer, } \\
\text { warnet, } \\
\text { minimarket, } \\
\text { warung kecil } \\
\text { penjulan } \\
\text { meubel, } \\
\text { warung kecil, } \\
\text { fotocopy/pen- } \\
\text { jualan ATK } \\
\text { dan apotik }\end{array}$ & 9,7902 & $\begin{array}{l}\text { Kelurahan } \\
\text { Kambu dan } \\
\text { Lalolara }\end{array}$ & $\begin{array}{l}\text { Data } \\
\text { didapatkan } \\
\text { berdasarkan } \\
\text { survey primer } \\
\text { yaitu dengan } \\
\text { cara } \\
\text { menghitung } \\
\text { masing- } \\
\text { masing luas } \\
\text { tiap usaha }\end{array}$ \\
\hline Rekreasi & $\begin{array}{l}\text { Ruang } \\
\text { terbuka } \\
\text { hijau, } \\
\text { tambak, } \\
\text { tanah } \\
\text { terbuka }\end{array}$ & Terbangun & $\begin{array}{l}\text { Game Center, } \\
\text { rental VCD, } \\
\text { persewaan } \\
\text { komik dan } \\
\text { lapangan futsal } \\
\text { indoor }\end{array}$ & 0,5225 & $\begin{array}{l}\text { Kelurahan } \\
\text { Kambu dan } \\
\text { Lalolara }\end{array}$ & $\begin{array}{l}\text { Data } \\
\text { didapatkan } \\
\text { berdasarkan } \\
\text { survey primer } \\
\text { yaitu dengan } \\
\text { cara } \\
\text { menghitung } \\
\text { masing- } \\
\text { masing luas } \\
\text { tiap usaha }\end{array}$ \\
\hline Penunjang & $\begin{array}{l}\text { Ruang } \\
\text { terbuka } \\
\text { hijau, } \\
\text { tambak, } \\
\text { tanah } \\
\text { terbuka }\end{array}$ & Terbangun & $\begin{array}{l}\text { Butik, bengkel, } \\
\text { salon dan } \\
\text { laundry }\end{array}$ & 3,4526 & $\begin{array}{l}\text { Kelurahan } \\
\text { Kambu dan } \\
\text { Lalolara }\end{array}$ & $\begin{array}{l}\text { Data } \\
\text { didapatkan } \\
\text { berdasarkan } \\
\text { survey primer } \\
\text { yaitu dengan } \\
\text { cara } \\
\text { menghitung } \\
\text { masing- } \\
\text { masing luas } \\
\text { tiap usaha }\end{array}$ \\
\hline
\end{tabular}

Jika melihat perbandingan penggunaan lahan tahun 2006 dengan tahun 2010 sangat mengalami banyak perubahan terutama pada lahan ruang terbuka hijau yang pada tahun 2010 sudah berubah menjadi lahan permukiman ataupun perdagangan dan jasa. Akan tetapi tidak hanya terjadi pada ruang terbuka hijau, melainkan pada lahan tambak, rawa, semak maupun tanah terbuka sangat banyak yang mengalami perubahan lahan menjadi lahan terbangun. Berikut merupakan perbandingan penggunaan lahan tahun 2006 dan tahun 2010 .

\section{Kesimpulan Dan Rekomendasi}

\section{Kesimpulan}

Keberadaan Universitas Haluoleo membawa banyak perkembangan bagi kawasan sekitarnya. Selain itu, pertambahan jumlah penduduk juga menjadi salah satu akibat dari keberadaan universitas tersebut. Berdasarkan hasil analisis yang dilakukan terlihat bahwa keberadaan universitas sangat membawa pengaruh terhadap perubahan tata guna lahan disekitarnya. Hal ini ditandai dengan berkembangnya aktivitas ekonomi yang berimplikasi banyaknya lahan terbangun. Adapun aktivitas yang paling banyak tersebar di wilayah studi 
2006

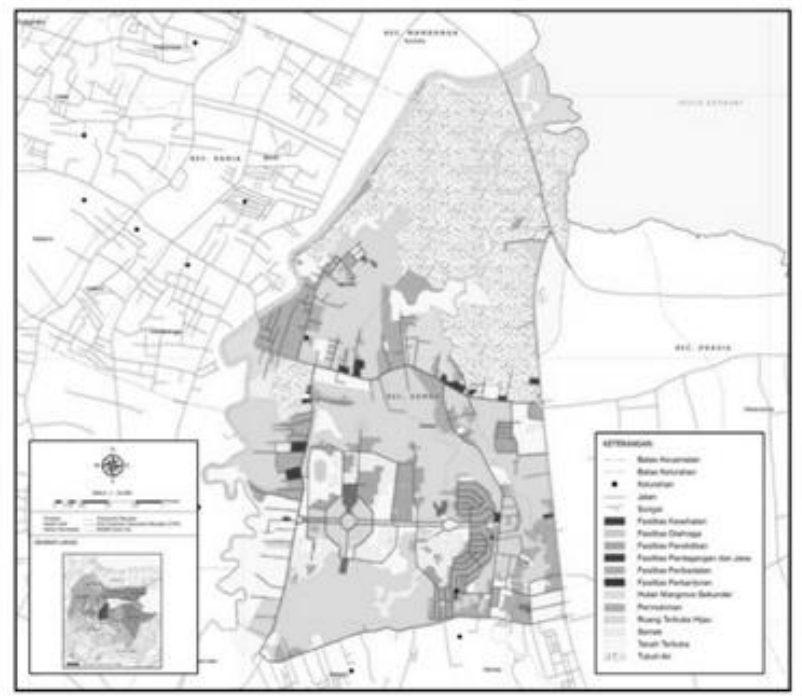

2010

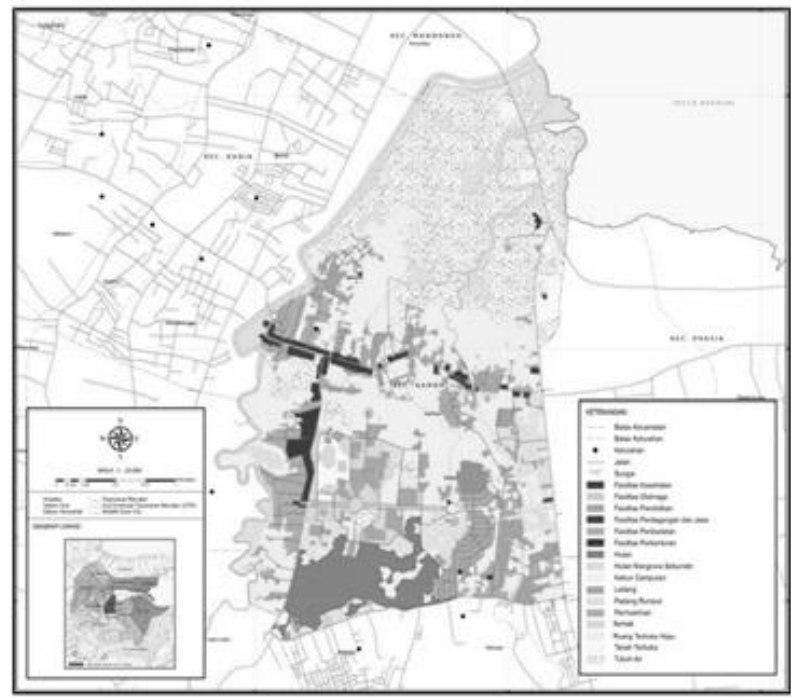

Gambar 2. Perbandingan penggunaan lahan tahun 2006 dan tahun 2010 di wilayah studi

yaitu aktivitas perdagangan dan jasa seperti munculnya kompleks pertokoan di sepanjang jalan utama menuju kampus. Aktiivtas yang muncul lainnya yaitu seperti adanya aktivitas bermukim, rekreasi dan penunjang dimana seluruh aktivitas tersebut mempunyai tujuan utama yaitu untuk memenuhi kebutuhan mahasiswa. Aktivitas yang muncul tersebut tersebar di kedua kelurahan wilayah studi yaitu Kelurahan Lalolara dan Kelurahan Kambu. Aktivitas yang lebih banyak muncul berada di Kelurahan Lalora hal ini disebabkan karena letak kelurahan ini berada sangat dekat dari Universitas Haluoleo dan kelurahan ini terletak sepanjang jalan poros utama menuju kampus yaitu Jalan MT. Haryono dan Jalan H.M.E Mokodompit. Sedangkan perkembangan aktivitas khususnya perdagangan dan jasa untuk Kelurahan Kambu sangat kurang hal ini disebabkan karena kelurahan ini tidak dilalui oleh jalur utama menuju kampus serta jauh dari jangkauan kampus.

\section{Rekomendasi}

Ada beberapa rekomandasi yang diajukan dalam penelitian tersebut. Adapun rekomendasi ditujukan kepada masyarakat maupun pihak pemerintah yang terkait.

a. Rekomendasi kepada pihak Universitas Haluoleo

Adanya penegasan mengenai peraturan mengenai lamanya berkuliah (sistem DO) di Universitas Haluoleo agar lebih menekan padatnya mahasiswa di sekitar Universitas Haluoleo. Hal ini perlu dilakukan karena seperti yang kita ketahui, setiap tahunnya kampus menerima mahasiswa yang tidak sedikit.

b. Rekomendasi kepada pihak masyarakat

- Adanya kesadaran bagi masyarakat terutama bagi para pelaku usaha untuk membangun usaha dengan kondisi yang layak agar terlihat teratur dan tidak semerawut. Hal tersebut perlu dilakukan mengingat kondisi perdagangan dan jasa khususnya di sepanjang jalan H.M.E Mokodompit masih banyak bangunan yang terbuat dari papan dan sangat tidak teratur penempatannya.

- Perlu dilakukan pendataan atau masyarakat yang mempunyai kesadaran untuk mendatakan dirinya pada masing-masing kelurahan agar diketahui jumlah usaha atau aktivitas ekonomi formal agar pemerintah sekitar bisa membatasi jumlah 


\section{Pengaruh Keberadaan Universitas Haluoleo Terhadap Perubahan Tata Guna Lahan...}

kebutuhan aktivitas di kawasan tersebut. Tujuan adanya rekomendasi ini agar status kepemilikan dari para pelaku usaha ini menjadi legal.

c. Rekomendasi kepada pihak pemerintah daerah

- Adanya peraturan dari pemerintah tentang izin mendirikan bangunan sehingga perdagangan dan jasa terlihat lebih teratur dan tidak semerawut. Sehingga dengan adanya peraturan tersebut masyarakat atau para pelaku usaha memiliki kesadaran untuk membangun usaha dengan kondisi yang layak.

- Adanya penataan aktivitas ekonomi khususnya disepanjang jalan H.M.E Mokodompit. Penataan aktivitas ekonomi ini terutama dilakukan ke jenis usaha yang masih bangunannya masih terbuat dari papan saja karena jenis aktivitas tersebut terlihat sangat kumuh apabila tidak dilakukan penataan tersebut.

\section{Daftar Pustaka}

Acmadi, 2003. Metodologi Penelitian. Jakarta: Penerbit Bumi Aksara

Anonimus. 2010. Kota Kendari Dalam Angka. Biro Pusat Statistik. Kendari 2010. Kecamatan Kambu Dalam Angka. Biro Pusat Statistik. Kendari

. 2010. Kelurahan Kambu Dalam Angka. Kelurahan Kambu. Kendari

2010. Kelurahan Lalolara Dalam Angka. Kelurahan Lalolara. Kendari

2010. Peta Tanah, Bappeda Provinsi Sulawesi Tenggara, Kendari.

Akashi, 1996. Sistem Perencanaan Tata Guna Lahan Perkotaan Jepang.

Bintarto, R. 1989. Interaksi Desa Kota dan Permasalahannya. Jakarta: Penerbit Ghalia.

Catanese, Anthony. J dan J. James. C. Snynder.1986. Pengantar Perencanaan Kota. Jakarta: Penerbit Erlangga.

Chapin, F Stuart and E. Keiser, 1979. Urban land Use Planning. United State of America: The Board of Trustees of The University.

Daldjoeni. 1998. Geografi Kota dan Desa. Bandung: Penerbit PT Alumni

Daldjoeni. 1978. Seluk Beluk Masyarakat Kota. Bandung: Penerbit PT Alumni

Jayadinata, Johara T. 1986. Tata Guna Tanah dalam Perencanaan Pedesaan, dan Wilayah. Bandung: Penerbit Institut Teknologi Bandung (ITB).

Nasir. 1983. Metode Penelitian. Jakarta: Ghalia Indonesia

Maleong, Lexy. 2006. Metodologi Penelitian Kualitatif. Bandung: PT Remaja Rosdakarya

Pusat Bahasa Departemen Pendidikan Nasional. 2001. Kamus Besar Bahasa Indonesia. Jakarta: Balai Pustaka

Rencana Tata Ruang Wilayah Kota Kendari Tahun 2000-2010

Rustiadi, Ernan. 2009. Perencanaan dan Pengembangan Wilayah. Jakarta: Crestpent Press dan Yayasan Pustaka Obor Indonesia

Sapurbawati, Oktriana.2006. "Pengaruh Keberadaan Kampus terhadap Perkembangan Aktivitas Kawasan Sekitarnya (Studi Kasus: Kampusa Universitas Jendral Soedirman Purwokerto), Tugas akhir tidak diterbitkan, Program Studi S1 Perencanaan Wilayah dan Kota, Fakultas Teknik Universitas Diponegoro, Semarang.

Sarwono, Jonathan. 2011. “Mixed Methods”. Jakarta: PT Elex Media Komputindo

Subagyo, P. Joko. 2004. Metode Penelitian dalam Teori dan Praktek. Jakarta: Penerbit Rineka Cipta

Sugiyono. 2005. Statistika untuk Penelitian. Bandung: Penerbit CV Alfabeta

Tarigan, Robinson. 2003. Perencanaan Pembangunan Wilayah. Jakarta: PT Bumi Aksara

Wahyuni, Novianti. 2002. "Pengaruh Keberadaan Perguruan Tinggi terhadap Perkembangan Struktur dan Bentuk Kawasan Pinggiran (Studi Kasus: Kampus Unnes Sekaran)”, Pra tesis tidak diterbitkan, Program Studi Magister Perencanaan Wilayah dan Kota, Fakultas Teknik Universitas Diponegoro, Semarang. 
Yunus,Sabari.2005. “Struktur Tata Ruang Kota”. Yogyakarta: Pustaka Pelajar

Yusran, Aulia.2006. "Kajian Perubahan Tata Guna Lahan pada Pusat Kota Cilegon”. Tesis tidak diterbitkan, Program Studi Magister Pembangunan Wilayah dan Kota, Konsentrasi Perencanaan Pembangunan Wilayah dan Kota, Fakultas Teknik Universitas Diponegoro, Semarang.

UU RI nomor 26 Tahun 2007 tentang Penaatan Ruang

"Definisi Universitas" http://id.shvoong.com. Diunduh tanggal 2 Desember 2011

"Sejarah Universitas Haluoleo" http://www.unhalu.ac.id. Diunduh tanggal 2 Desmber 2011 
88 Pengaruh Keberadaan Universitas Haluoleo Terhadap Perubahan Tata Guna Lahan...

JURNAL WILAYAH DAN LINGKUNGAN, 2 (1), 73-88 